\title{
界面活性骩共存下におけるニッケル(III)イオンと 1-ピロリジン
}

\section{カルボジチオ酸イオンとの錯体生成反応 ${ }^{122}$}

(1976 年 12 月 7 日受理)

\author{
伊藤三郎*・緒方敏夫* 一山田勝利*林 㴚次郎**
}

\begin{abstract}
水に難溶な鍇体を生成するため水溶液中では生成速度測定の困難なニッケル（II）イオンと1ーピロリ シシンカルボジォオ酸 (PDT) イオンとの錹体生成反応を, 非イオン性界面活性郕 Triton X-100 を共存 させ錯体を可溶化し、ストッフドファー法を用いてその反応速度を娜定することにより，反応機構およ び速度定数を明らかにした。

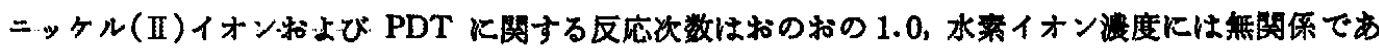
った。したがってこの反応はニッケル(II)イオンと解恼したPDT イオンとの1：1錯体生成反応が律 速であることを示した。その速度定数は $(2.60 \pm 0.03) \times 10^{4} \mathrm{dm}^{8} \cdot \mathrm{mol}^{-1} \cdot \mathrm{s}^{-1}$ であり，二゙ッケル(II)イオ ンからの配位水の解離速度と一致した。
\end{abstract}

\section{1 曾}

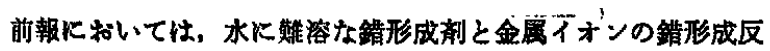

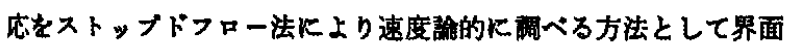
活性用による錯形成剂の可溶化法の利用を提案しだ)。この手法 住抽出，分離操作の制䄪から溶媒抽出法では調へることのできな い分単位より短い反応半減期をるつ速い反応系の解析を可能化す ると考えられる。

一方、錯形成刘は水飞可溶であるが，生成する錯体が解浴なた め飞錯体生成反応の速度諭的解析ができない系がある。このよう な系についてる界面活性削により水に難溶な鏻体の可客化ができ ればストッブドフロー法による反応の解析が可能となる。界面活

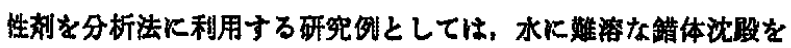
生成するため安定な吸光度測定がでるい系において，界面活性 剂を用いて沈股を可客化し罗光光度定量を行なった報告がなされ

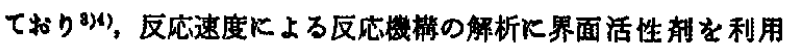
し得ることが考えられる。

本報ては，分析用錯形成剤としては䇣用されているが金属イオ ンとの錯形成反応機構についてはあまり知られていない1ーピ口

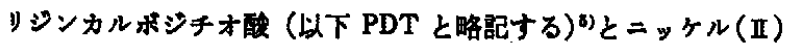
イオンとの錯形成反応を，錯体の可客化制として非イオン性界面

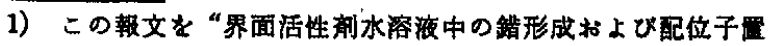

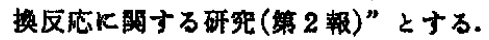

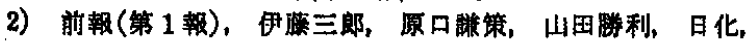
$1977,1137$.

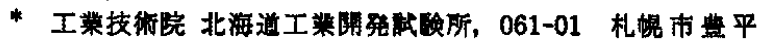
区巢月寒

**山口大学文理学部, 753. 山口市吉田

3）四条好婎, 武内次夫, 分析化学, 16，51(1967).

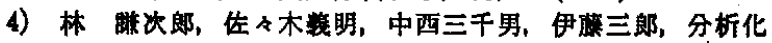
学, 19, 1673(1970).

5）進藤英二，菻藤 守，化学の領城，21，206(1966).
活性雵 Triton X-100を用い,ストッフドフロー法火より反応速 度を测定し，反応機構を推定しよらと武みた。この系の反応機構 研究例の少ない理由は PDT が水下可溶ではあるが有機溶媒に 不溶であり，生成する錯体性道水水不溶で沈股を生ずるが有機

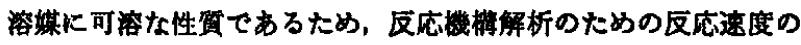

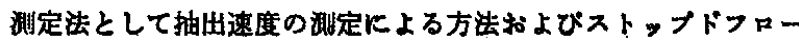
法が道用できないこととよると思われる。

PDT は通常フンモニウム㙁,ナトリウム㙁（以下标のおの APDT, NaPDT と略記する)が使用されるため実楀においても 雨塩を用いて行なった。

\section{2 喊㠑および装而}

\section{1 乘}

ニッケル(II) 溶液 : 特級硝酸ニッケルを乐に溶解し, EDTA 滴 定で湿度を標定し原液とした。

PDT 溶液: APDT 和光純蔧製原子吸光分析用, NaPDT は

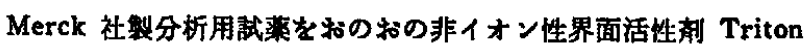
$\mathrm{X}-100$ (ポリオキシエチレングリコール=p-(1,1,3,3-テトラメチ ルブチル)フェニルェーテル; $\left(\mathrm{CH}_{3}\right)_{2} \mathrm{CCH}_{2} \mathrm{C}_{(}\left(\mathrm{CH}_{3}\right)_{2} \mathrm{C}_{6} \mathrm{H}_{4} \mathrm{OH}\left(\mathrm{C}_{4}\right.$

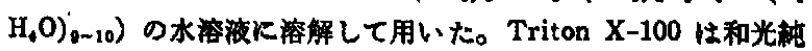
乘製を用いた。

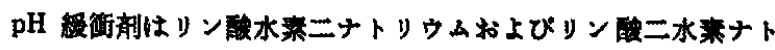

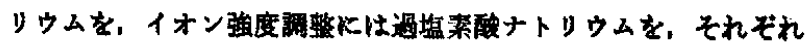
市眅特級品をそのまま用いた。

\section{2 装}

反応速度の湘定はニニオン技研製 RA-1300 型を用いた。反応

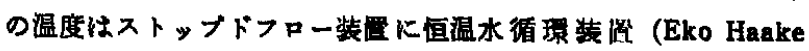

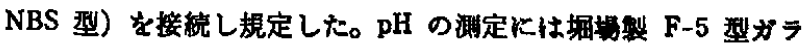

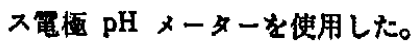




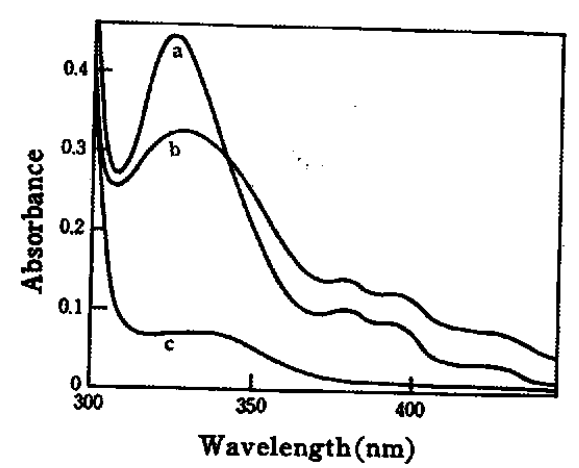

Fig. 1 Absorption curve of Ni(II)-APDT complex [APDT] : $1.00 \times 10^{-8} \mathrm{~mol} \cdot \mathrm{dm}^{-8}$ $\left[\mathrm{Ni}^{2+}\right]: 1.00 \times 10^{-5} \mathrm{~mol} \cdot \mathrm{dm}^{-3}$ pH : 7.05, Temperature : $20^{\circ} \mathrm{C}$ a : In the presence of Triton X-100, $0.1 \mathrm{w} / \mathrm{v} \%$ $b:$ In the absence of Triton X-100 c : Reagent blank

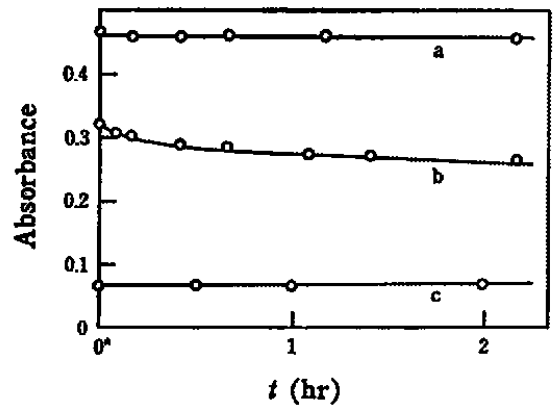

Fig. 2 Time dependence of the absorbance of Ni-APDT complex at $325 \mathrm{~nm}$ in the presence of surfactant

[APDT] : $1.00 \times 10^{-3} \mathrm{~mol} \cdot \mathrm{dm}^{-8}$

$\left[\mathrm{Ni}^{2+}\right]: 1.00 \times 10^{-5} \mathrm{~mol} \cdot \mathrm{dm}^{-3}$

$\mathrm{pH}: 7.05$, Temperature $: 20^{\circ} \mathrm{C}$

$a$ : In the presence of Triton $X-100,0.1 \mathrm{w} / \mathrm{v} \%$

$b$ : In the absence of Triton X-100

c : Reagent blank

* The absorbances at $t=0$ in this figure show the values at one minute after the reaction started.

\section{3 英験および結果}

\section{1 ニッケル(II)-APDT 錯体の吸收曲線}

反応速度は生成錯体K上る特定波镹の吸光度時間变化を泚定し て求めるため，錯体の吸収特性を知り吸光度测定波辰を決定する 必要がある。四1下=ッケル(II)-APDT 錯体の吸收曲線を示し

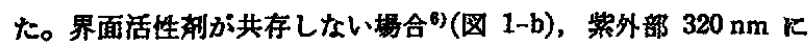

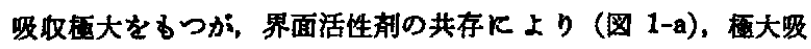
收波長恃わずかながら短波長㑡 $325 \mathrm{~nm}$ Kシフトするとともにこ の波長では1.5倍の吸光度の增加を示し，逆に $340 \mathrm{~nm}$ 以上では 吸光度の減少が認められる。

因 2 K $325 \mathrm{~nm}$ に拉ける吸光度の時間変化を示した。界面活性 剂が共存しないときにはニッケル(II)-PDT 錯体は水に不溶のコ

6）この錯体は不溶性の=ロイド状沈殿を形成するので，界面 活性都のない揞合には正しい爱収曲線とはいえないが，界 面活性剖共存の场合と比筊するため澌定した。

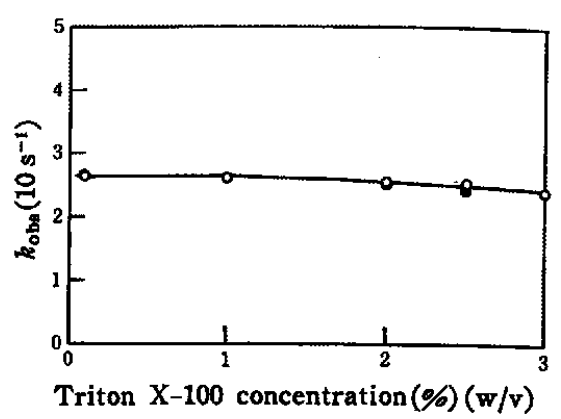

Fig.3 Effect of surfactant concentration on the reaction rate of the complex formation

[PDT] : $1.00 \times 10^{-8} \mathrm{~mol} \cdot \mathrm{dm}^{-8}$

$\left[\mathrm{Ni}^{2+}\right]: 1.00 \times 10^{-5} \mathrm{~mol} \cdot \mathrm{dm}^{-8}$

$\mathrm{pH}: 7.05, \mu=0.1$, Temperature : $25^{\circ} \mathrm{C}$

$O:$ APDT, $:$ NaPDT

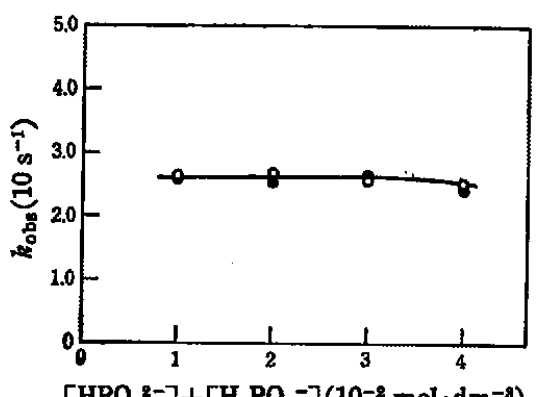

$\left[\mathrm{HPO}_{4}{ }^{2-}\right]+\left[\mathrm{H}_{2} \mathrm{PO}_{4}^{-}\right]\left(10^{-2} \mathrm{~mol} \cdot \mathrm{dm}^{-9}\right)$

Fig. 4 Effect of buffer on the reaction rate

[PDT] : $1.00 \times 10^{-8} \mathrm{~mol} \cdot \mathrm{dm}^{-8}$

$\left[\mathrm{Ni}^{2+}\right]: 1.00 \times 10^{-5} \mathrm{~mol} \cdot \mathrm{dm}^{-8}$

pH : 7.05, $\mu=0.1$, Temperature : $25^{\circ} \mathrm{C}$

$\mathrm{O}:$ APDT, $:$ NaPDT

ロイド状沈股を形成し，時間ととすに取光度墭少ナる (这 2-b)。 界面活性郕が共存する場合は錯体はミセルに可溶化され，安定な 吸收を示し(図 2-a)，沈貶の生成による吸光度への影敏は除去さ れ，鉝体生成速度の莭定が可能であることを示す。NaPDT につ いても APDT とまったく同様な結果が得られた。この結果に基 つき反応速度の娜定波畏は两壏ともに $325 \mathrm{~nm}$ とした。

\section{2 反応速度の測定}

速度の洞定に供するニッケル(II) 溶液は $2.00 \times 10^{-6} \mathrm{~mol} \cdot \mathrm{dm}^{-8}$ の溶液を用いた。界面活性剂を共存させた PDT 溶液はニッケル に関し擬一次反応となるようニッケルに対し大過剩である 50 倍

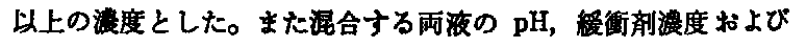
イオン強度 $(\mu=0.1)$ は同一にした。これらの溶液を速度澌定装 淖中の 2 個のシリンダー中におのおの注入し，一定量を急速に混 合し，325 nm における吸光度の時間変化を湖定した。

測定した酸光度变化をるとにニッケル(II)イォンの初簧度と時 間 $t$ 後の吸光度の比の自然対数值を時閻 $t$ に対しブロットすると PDT の湿度を変えてす原点を通る直線関係を示し，この㑯向は

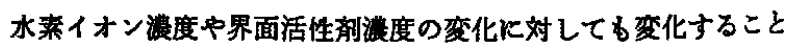
はなく、ニッケル(I)イオンについての㨝一次反応となっている ことを示す。そこでこの直線の勾配をおのおのの条件に対応する 条件速度定数 $k_{\text {ob }}$ とした。 


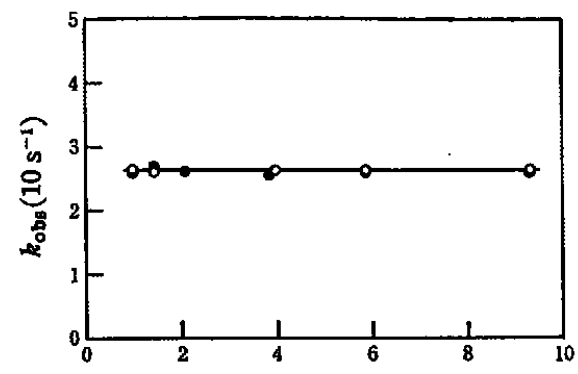

$\left[\mathrm{H}^{+}\right]^{-1}\left(10^{7} \mathrm{~mol}^{-1} \cdot \mathrm{dm}^{8}\right)$

Fig. 5 Reaction rate as a function of $\left[\mathrm{H}^{+}\right]$

[PDT] : $1.00 \times 10^{-8} \mathrm{~mol} \cdot \mathrm{dm}^{-8}$

$\left[\mathrm{Ni}^{2+}\right]: 1.00 \times 10^{-8} \mathrm{~mol} \cdot \mathrm{dm}^{-8}$

$\mu=0.1$, Temperature : $25^{\circ} \mathrm{C}$

$O:$ APDT, $:$ NaPDT

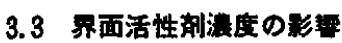

可容化刘としての Triton X-100 の $k_{\mathrm{obs}}$ への浱度の影謷を調 べた（図 3）。その結果 $3.0 \mathrm{w} / \mathrm{v} \%$ までほ注一定値をとり，その 影整は見られない。しかしさらに滈いTriton X-100 婊度では再 現性が低下する倾向を示した。以後の㬰験ではブランクの曼光度 を低くすることる考感し Triton X-100 濃度は $0.1 \mathrm{w} / \mathrm{v} \%$ とし た。

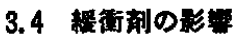

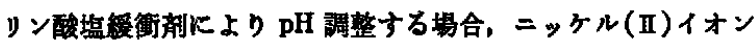

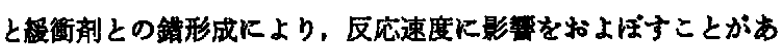

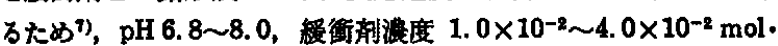

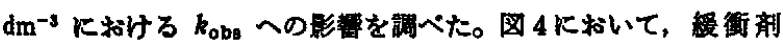
港度が高い部分で

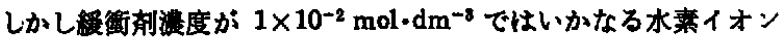
搌においてるその影签は無視しうる程度である。以後の実倹に

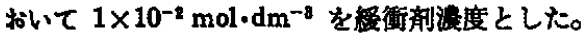

\section{5 水来イオン㵊度の影腊}

$\mathrm{pH}$ 6.8 8.0 まで変化させ， $k_{\mathrm{obs}}$ への水菜イオン濃度の影

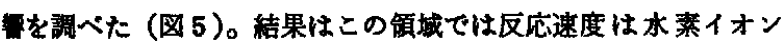
满度に依存しないことを示す。

\subsection{PDT に関する反応次数}

PDT 淟度を $0.5 \times 10^{-8} \sim 1.5 \times 10^{-8} \mathrm{~mol} \cdot \mathrm{dm}^{-3}$. まで变化させ， 各浱度に対応する $k_{\mathrm{obs}}$ を $y$ 軸に PDT 涉度に対してプロットす ると原点を通る良好な直線関係が得られた（図6）。したがって PDT 漶度に関する反底次数は1.0である。

\section{7 律速反応と速度定数}

ニッケル(II)-PDT 錯体の組成をモル比法により求めると 1： 2 の結果が得られた。またPDT の酸解離定数が $K=10^{-2.96}$ 日) であり、この実験で行なわれた $\mathrm{pH}$ 領域では反応速度に対して水

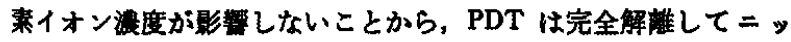
ケル(II)イオンと錯形成反応を行なっていると考えられる。した がって錯体生成の反応はつぎの二式にしたがって進行すると考え られる。

7）山田勝利，中川毒一，原口策，伊藤三郎，日化，1975， 294.

8) R. Zahradnik, P.Zuman, Collect. Czech. Chem. Com. mun., 24, 1132(1959)

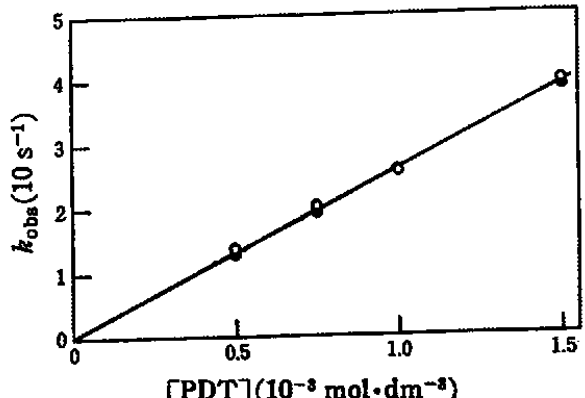

Fig. 6 Reaction rate as a function of PDT concentration

$\left[\mathrm{Ni}^{2+}\right]: 1.00 \times 10^{-5} \mathrm{~mol} \cdot \mathrm{dm}^{-8}$

$\mathrm{pH}: 7.05, \mu=0.1$, Temperature $: 25^{\circ} \mathrm{C}$ $O:$ APDT, $:$ NaPDT

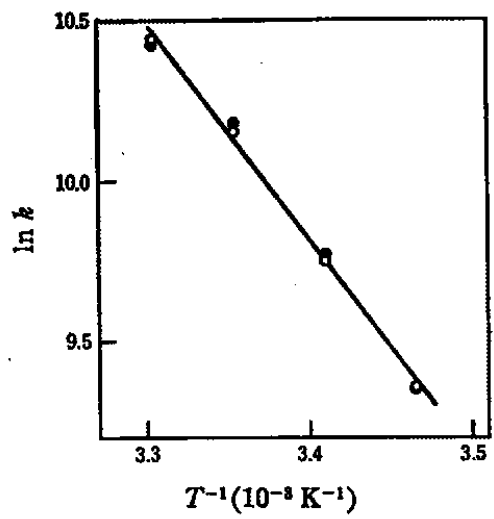

Fig.7 Arrhenius plot

$O:$ APDT, $:$ NaPDT

$$
\begin{aligned}
& \mathrm{Ni}^{2+}+\mathrm{R}^{-} \stackrel{k}{\longrightarrow} \mathrm{NiR}^{+} \\
& \mathrm{NiR}^{+}+\mathrm{R}^{-} \longrightarrow \mathrm{NiR}_{2}
\end{aligned}
$$

反応次数について得られた結果からは，反応速度K対し PDT のみが1次で関与していることから，この錯形成反応ではニッヶ ル(II)イオンと PDT の 1:1 錯形成反応((1)式)が律速てある ことが明らかである。反応の速度式は（3）式で表わされ，速度定 数 $k$ 住実椡した $k_{\mathrm{oba}}$ から(4)式化より求めることができる。

$$
\begin{aligned}
& -\frac{\mathrm{d}\left[\mathrm{Ni}^{2+}\right]}{\mathrm{d} t}=k\left[\mathrm{Ni}^{2+}\right]\left[\mathrm{R}^{-}\right] \\
& k_{\mathrm{obg}}=k\left[\mathrm{R}^{-}\right]
\end{aligned}
$$

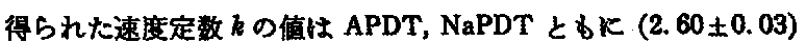
$\times 10^{4} \mathrm{dm}^{8} \cdot \mathrm{mol}^{-1} \cdot \mathrm{s}^{-1}$ であり，塩による相连は諗められなかった。

\section{8 活性化ハラメーター}

速度定数の温度依存性を調へたた結果を図 7 に宗した。APDT, NaPDT ともに， $15 \sim 30^{\circ} \mathrm{C}$ の㑚定温度䛔域で一致した直線関保が 得られこの点からる両壏による反応に相違がないことが明らか であった。これらの結果から Arrhenius の活性化エネルギー $E_{\text {a }}$ 活性化エンタルビー $\Delta H^{*}$, 活性化自由エネルギー $\Delta F^{*}$, 活性 化エントロピー $\Delta S$ をおのおの求め表 1 K示した。表中右相 は Connick らが NMR で求めたニッケル(II)イオンからの㞎位 水の解離速度から得られた值字ずす。 


\section{4 結果の考素}

水に難溶な錯形成郕と金属イオンとの錯形成反庶，あるいは水 に可溶な錯形成郕であっても生成する鍇体が氷に不溶で沈殿を生 成する場合には、ストップドフロー法による反度速度の追跡がで きない。とくに後者は，生成する錆体がイソブチルメチルケトン などの有譏溶媒に可溶であっても抽出速度の湘定に上る方法す適 用できないため，錯体生成速度から反応機構を調べた例はない。

本報では皮に不溶な錯体を界面活性剂ミセルの溶解作用により 均一液とし、ストッブドフロー法による反応速度の䁌定に界面 活性刻の溶解作用を利用する手法が有効なことを確がた。この 手法を用いる場合，界面活性成の反応速度飞対する影䇺はつねに 考虚する必要があるが，本研究において性离い界面活性剂濃度に おいて吸头度の時間変化の测定の再現性が低下する影繁，お゙よび 錯体のモル吸光俰数が界面活性詴が共存しない埋合のそれにくら べ大きくなる傾向を示したが，反応速度に值接関与する顯著な影 要はなかった。しかし通常ミセル淮は完全に均一な溶液状熊と はいえず：ミセル界面近傍は特な反応の場と考えられることす 多く，異なった反応系や界面活性剂については反応速度に直接影 霖することが考光られる10)。たとえば，陽イオン界面活性剂ベン ジルジチルテトテデシルフンモニウムニクロリド共存中におけ る鈰と 1-(2-ピリジルアゾ)-2-ナフトール(PAN)の錯形成速度

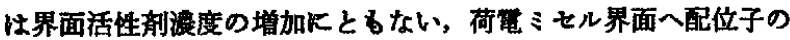
一部分が配向し，この配位子が銅（II）イオンとは反応し難いこと 火起因して反応速度が隇少することが報告されている゙1。

9) J.W. Neely, R. E. Connick, J. Am.Chem.Soc., 94, 3419, 8646(1972).

10) J.H. Fendler, E. J. Fendler, "Catalysis in Micellar and Macromolecular Systems", Academic Press, New York (1975) p. 251.

11）小原人司, 分析化学, 25,350 (1976).
Table 1 Activation parameters

\begin{tabular}{|c|c|c|}
\hline & $\mathrm{Ni}^{2+}+\mathrm{R}-\longrightarrow \mathrm{NiR}^{+}$ & $\begin{array}{c}\mathrm{Ni}\left(\mathrm{H}_{2} \mathrm{O}\right)_{6}^{2+} \\
\left.\mathrm{Ni}\left(\mathrm{H}_{2} \mathrm{O}\right)_{5}^{2+}+\mathrm{H}_{2} \mathrm{O}^{a}\right)\end{array}$ \\
\hline$E_{\mathrm{a}}\left(\mathrm{kJ} \cdot \mathrm{mol}^{-1}\right)$ & $52.3 \pm 0.8$ & \\
\hline$\Delta H^{\circ}\left(\mathrm{kJ} \cdot \mathrm{mol}^{-1}\right)$ & $50.2 \pm 0.8$ & 58.1 \\
\hline$\Delta F^{*}\left(\mathrm{~kJ} \cdot \mathrm{mol}^{-1}\right)$ & $47.7 \pm 0.2$ & \\
\hline$\Delta S^{*}\left(\mathrm{~J} \cdot \mathrm{mol}^{-1} \cdot \mathrm{K}^{-1}\right)$ & $7.9 \pm 2.8$ & 36.4 \\
\hline
\end{tabular}

a) Connick et al. ").

また著者らは非イオン性界面活性剂 (Triton X-100, X-305, およひ Tween \#20) ミセル溶液に溶解した 8-キノリノールと ニッケル(II) イオンとの錯形成反応において, ニッケル(II)イオ ンと直接反応し得る 8-キノリノールが界面活性成の增加にとる ない、ミセル内部々水溶液相との間の分配に起因して隇少するた めと思われる反応速度の低下を見いだした2。一般に界面活性剂 共存下における錯形成反応は本埌の上らに界面活性剂の影繁の少 ない揚合はまれであって，直接間接に影䈏を受けるるのと考えら れ, 界面活性郕の可溶化作用を租用する錯形成についてはさらに 検討の必要があろら。

これまでに调べられた多くの錯形成反応が金属イオンからの兄 位水の解離を律速段階とするいかゆる Eigen 機構皇)で進行する 反応であったと同様に,この反応る $1: 1$ 錯形成反応に律速され, その速度定数がニッケル(正)イオンからの配位水の解離速度 3.0 $\times 10^{4} \mathrm{~s}^{-113)}$ と一致し活性化エンタルピー9すは注一致しているこ とから，律速段陆はニッケル(I) イオンからの配位水の解雄であ ることが明らかとなった。

（1976 年 4 月，日本化学会第 33 春平年会発表）

12) M. Eigen, R. W. Wilkins, in Mechanisms of Inorganic Reaction, Advances in Chemistry Series, No. 49, American Chemical Society, Washington, D.C., 1955.

13）文献 9）の $\Delta H^{*} ， \Delta S^{*}$ から訫算した值を示した。

\section{Kinetics of Complexation Reaction between Nickel(II) and 1-Pyrrolidinecarbodithioate in the Surfactant Solution

\author{
Saburo ITo*, Toshio Ogata*, Katsutoshi Yamada* \\ and Kenjiro Hayashi** \\ * Government Industrial Development Laboratory, Hokkaido ; \\ Higashi-Tsukisamu, Toyohira-ku, \\ Sapporo-shi 061-01 Japan \\ Yoshida, Yamaguchi-shi 753 Japan
} \\ ** Faculty of Literature and Science, Yamaguchi University;}

The rate of complexation reaction between nickel(II) and 1-pyrrolidinecarbodithioate (PDT) in the presence of nonionic surfactant, Triton $\mathrm{X}-100$, has been studied by a stopped-flow method over the $\mathrm{pH}$ range of $6.8 \sim 8.0$, and at $288 \sim 303 \mathrm{~K}$.

Since the complexation reaction between nickel(II) and PDT is a precipitation reaction in aqueous solution, the rate of this reaction can not be followed by the measurement of absorbance. In the presence of nonionic surfactant, as the chelate of nickel(II) with PDT dissolved into micelle, the kinetics of this reaction could be studied with stopped-flow method.

The reation was of first-order with respect to nickel(II) ion and PDT, and independent of a hydrogen ion concentration. The surfactant did not have a direct influence on the rate of this reaction. On the basis of these results, it was found that the rate-determining step is the $1: 1$ chelate forming reaction between nickel(II) ion and PDT ion $\left(R^{-}\right)$:

$$
\mathrm{Ni}^{2+}+\mathrm{R}^{-} \stackrel{k}{\longrightarrow} \mathrm{NiR}^{+}
$$


The estimated rate constant, $k=(2.60 \pm 0.03) \times 10^{4} \mathrm{dm}^{8} \cdot \mathrm{mol}^{-1} \cdot \mathrm{s}^{-1}$ was in good agreement with that for dissociation of coordinated water molecule from nickel(II) ion.

The activation parameters of the rate-determining reaction were determined. The values are $E_{\mathrm{a}}:(52.8 \pm 0.8) \mathrm{kJ} \cdot \mathrm{mol}^{-1}, \Delta H^{*}:(50.2 \pm 0.8) \mathrm{kJ} \cdot \mathrm{mol}^{-1}, \Delta F^{*}:(47.7 \pm 0.2) \mathrm{kJ} \cdot \mathrm{mol}^{-1}$, and $\Delta S^{*}:(7.9 \pm 2.8) \mathrm{J} \cdot \mathrm{mol}^{-1} \cdot \mathrm{K}^{-1}$.

$\dagger$ Studies of Complexation and Ligand Substitution Reactions in the Aqueous Surfactant Solutions. II. 